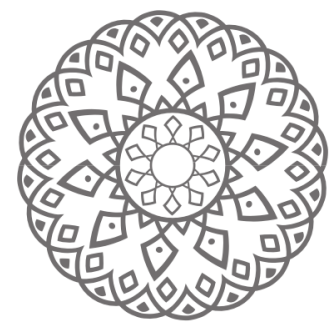

\title{
Analysis of Corporate Governance on ISLAMIC BANKING IN INDONESIA
}

\author{
Muhammad Nadratuzzaman Hosen, Nasimul Falah, \\ Fitriyani Lathifah
}

\begin{abstract}
Abstrak: Artikel ini mengkaji Corporate Governance dan kaitannya dengan regulasi nasional dan hukum Islam. Penelitian pada artikel ini difokuskan pada penerapan CG di Perbankan Syariah di Indonesia dengan menekankan pada aspek hukum dan nilai-nilai Islam dalam CG. Metode penelitian yang digunakan adalah metode kualitatif berbasis kajian terhadap literature dan dokumen. Penelitian ini menemukan bahwa beberapa Bank Islam, yang mengeluarkan aturan CG, belum memenuhi prinsip-prinsip yang terdapat dalam hukum Islam dan hukum positif. Dalam hal ini bank masih melakukan hal-hal yang tidak sesuai dengan hukum dalam menerapkan layanan mereka. Ada perbedaan penerapan CG berbasis Islam di Indonesia dan Malaysia. Dari itu, diperlukan penelitian lebih lanjut untuk mengkaji kebijakan yang tepat terkait dengan penerapan CG di perbankan Syariah. Penelitian ini merekomendasikan adanya rekonstruksi peraturan CG dari yang standar menjadi peraturan berbasis prinsip Islam dan hukum nasional.
\end{abstract}

Kata kunci: corporate governance, Bank Islam, prinsip Islam, hukum Nasional 
Abstract: This article demonstrates the concept of corporate governance (CG) in regards to regulations and Islamic teaching. It also investigates the implementation of CG in Islamic Banking in Indonesia emphasising the law aspects and Islamic values of the CG. This study uses a qualitative approach with interviews and literature analysis. This study found that some Islamic Banks, which issued the rules of CG, do not meet the philosophy of Islamic principles and Islamic law as well as positive law. These banks were committed fraud in implementing their financial services. The implementation of Islamic corporate governance in Indonesia is different from the one in Malaysia. Therefore, it is important to do further research to examine the right policy for the implementation of CG in Islamic banking. Finally, this research suggests the Islamic banks to reconstruct the regulation of corporate governance and shifted into Islamic corporate governance standard based on Islamic principles and national laws.

Keywords: corporate governance, Islamic bank, Islamic principles, national laws 


\section{Introduction}

Some studies indicate that the goal of CG is to maximize shareholder value (reference?). However, according to Lasghari (2004 corporate executives of the companies have been neglected the primary goal of the company to support the wealth of shareholders. Meanwhile, Klapper and Love (2004) consider good corporate governance (GCG) has a significant effect on performance and market value. Mitchell and Lehn's (1990) as quoted by Masulis, Wang and Xie (2007) state that implementing corporate governance is important to provide managerial executive proper incentives for maximizing value of shareholder.

Authors have demonstrated several aspects and approaches of CG, but none of them agreed to one similar definition of CG. For example, Cadbury (1992) proposes the definition of corporate governance as a system whereby a company is managed and controlled. Whereas, Turnbull (1999) defines corporate governance as a corporate system that focuses on internal controls in managing corporate risks by maintaining and improving corporate assets. The Organization for Economic Cooperation and Development (OECD, 1999) argues that corporate governance is a key element for improving economic efficiency and enhancing investor confidence, such as director, shareholder and stakeholder.

Other scholars, Chodhury and Alam (2013) define corporate governance as the rule of guidance control for achieving economic and social goals of the organization. The goals should manage the relationship between internal and external factors, such as matrix of economic, financial, legality, employees, manager, director, and social elements and minimize the risk of organization. Furthermore, they stated that corporate governance should be aimed for achieving welfare between the system and methodology of organizational behavior.

Meanwhile, Franzini (2009) argues that corporate governance does not have any relationship with the level and growth of investment in many countries revenue. Similarly, Sundaram and Inkpen (2004) demonstrate the conflict between the stock exchange and corporate scandals in 2001 and 2002, which led to criticizing the main goal of company to maximize value of shareholders.

Liu (2005) argues that many problems are typically caused by the 
failure of the system to protect the interests of shareholders. Uzun et al. (2004) review a board composition and corporate fraud. It shows that the supervisory and board of director are significantly committed the fraud at the company. Lorenzo (2007) states in his article on 'Business Ethics: Law as A Determinant of Business Conduct' that the business practitioners behavior is incompatible with the law in recent years.

Regarding the Islamic perspective, Hasan (2009) argues that definition of corporate governance should combine elements of taubid (unity of God), shura (compromise among people), and Islamic rules to maintain personal goals without neglecting duties and responsibilities on social welfare. Lewis (2007) shows that ethics, religion, and legal principles are the basic principles of Islamic finance law. Furthermore, Abeng (1997) also states that the role of business leaders is the key to build a corporate culture.

Based on the explanation above, this research aims at continuing previous research in the areas of corporate governance. I focus the analysis on corporate governance and Islamic laws governance related to prevention efforts of fraud in Islamic banking. The main purpose of this study is to explore the ideal corporate governance rules for Islamic banking which applies Islamic laws and Islamic legal as its philosophical foundation. This research examines how is the implementation of CG in an Islamic bank and refer it to the CG standards issued by the Central Bank of Indonesia (BI) in 2009.

\section{Discussion}

\section{Concept of Corporate Governance}

The concept of Corporate Governance (CG) in Islamic perspective has a similar meaning with "shariah governance" which is the vital and core aspect in implementing shariah principles in Islamic banking. Hanif (2018) argues that the scope of shari'ah governance covers shari'ah supervision and control, charitable operations, human resources, product development and organisation. Besides, Darmadi (2013) argues that it is important for certain firm or organisation to implement the principles of CG following organizational aspects such as transparency and responsibility. He also classifies several indexes in implementing CG in Islamic banking namely, shari'ah supervisory board (DPS), board of commissioner (BOC), board of director (BOD), 
board of committee internal control (CIC) and external audit, and risk management of CG implementation.

The availability of DPS is important to ensure the activities of an Islamic bank is compatible with Islamic law. In Indonesia, member of DPS is appointed by shareholders of the bank during its general meeting under the recommendation of Indonesian Council of Ulama (MUI). While, the role BOD is to mitigate conflict, if any, between shareholders and manager. Thus, the bank should hire an independent board to protect the rights of minority shareholders. The BOC represents the shareholders to conduct advisory and monitoring roles of the management. The member of BOC consists of shareholders and independent commissioner from outside firm. In this regard, the Central Bank of Indonesia provides a 'fit and proper test' for the candidates to be appointed as a member of BOD and BOC. The successful candidates will be selected during the general meeting. The study of Darmadi (2013) found that Bank Syariah Mandiri (BSM) and Bank Muamalat Indonesia (BMI) have the highest score of the CG performance among other Islamic Banks in Indonesia.

\section{The Rules of the National Committee on Corporate Governance Policy}

After experiencing the global crisis in 1997-1998, the Indonesian government through the Coordinating Ministry for Economic Affairs - Kementerian Koordinator Bidang Perekonomian established the National Committee on Corporate Governance Policy (KNKCG) based on the Decree of the Coordinating Ministry of Economic Number EP/31/M.EKUIN/08/1999. This committee issued a guideline of Good Corporate Governance (GCG) and has been revised and finalized in 2001.

\section{The Rules of Good Corporate Governance for Islamic Bank}

From 2006 to 2014, the Central Bank of Indonesia (BI) has been issued several rules regarding the Good Corporate Governance for Islamic Banks. For example, in 2006, the Central Bank of Indonesia (BI) issued a regulation, number 8/4/PBI/2006 on the 'Implementation of GCG for both commercial bank (BUK) and Islamic full-fledged (BUS)'. Moreover, in 2009, BI issued special regulation for an Islamic bank, number 11/33/PBI/2009 on the 'Implementation of GCG for 
BUS and Islamic Business Unit (UUS)'. In the next following year, in 2010, BI issued the Circular Letter of Central Bank of Indonesia (SE$\mathrm{BI})$, number $12 / 13 / \mathrm{DPbS}$ on 'Technical Guidance on Implementation of GCG for BUS and UUS' and followed by other regulation in 2014 on UUS in implementing GCG under commercial banks, number 6/24/PBI/2014.

\section{Good Corporate Governance Principles in Islamic Bank and National Law Act}

According to the Act of Islamic Bank No. 21 in 2008, the GCG principles should meet five elements in business activities; those are transparency, accountability, responsibility, professionalism, and fairness. The first is 'transparency' which means an act of openness in providing material and relevant information in the decision-making process. The second is 'accountability' that is the condition where decision makers are responsible for implementing rules and regulation of the bank. The third is 'responsibility' that is the compatibility of individuals' performance in the managerial board with laws and regulations of the bank management. The fourth is 'professionalism' or the ability to act objectively and free from other party's influence or pressure and the ability to commit to the development of Islamic Banks. The last is 'fairness' refers to justice and equity in fulfilling the rights of stakeholders based on general agreement, laws and regulations of the financial institution.

The Islamic Bank Act issues an official statement regarding the role of Islamic economic system development as a potential excavation and contribution to the development of national economic. The purpose of the development is to improve the Islamic values system to become national economic law. Moreover, words that are used in the Act of Islamic bank does not imply the term "independence", but words that are referred to 11/33/PBI/2009 Article 1 Number 10 junco Article 34.

\section{Good Corporate Governance Principles in Islamic Banking According to Islamic Teaching}

Scholars such as Lewis (2005), Suma (2002), and Shomad (2012) agreed that Islamic banking Act is part of the Islamic economic law. They proposed principles of banking law based on Islamic principles, 
those are aqidah and tauhidullah (unity of God), Tasyriizah (equivalent to the principle of al-Qur'an and As-sunnah), pure (kaffah), attitude (akhlaq), benefit and social principle, maqasid Islamic (the aims of life/ maslahah), agreement, willingness (ridha'iya or taradhin), legal equality (musawwamah), mutual help (ta'wawun); fair and justice (al-Adl), AlMizan (balanced), and certainty (Al-Qisth).

\section{Data and Method}

The data of this paper relies on the bibliographical study, annual report of GCG of each bank, and interviews with several experts of the bank. The focus of this study is several banks in Indonesia such as Bank Muamalat Indonesia (BMI), Islamic Bank A (just initial), Bank Syariah Mandiri (BSM), Bank Negara Indonesia (BNI) Syariah, Bank Rakyat Indonesia (BRI) Syariah, and Bank Jabar Banten (BJB) Syariah.

\section{Result and Finding}

\section{Corporate Governance: Legal Relation and Conflict of Interest}

a. Same Occupation in Another Bank

According to GCG regulation on Islamic banking, Number $11 / 33 / \mathrm{PBI} / 2009$, employees can have the same occupation in another bank if it is regulated in GCG regulation. In this regard, the board of commissioners has been regulated this matter in Article 16 and DPS regulated at Article 50. However, the same regulation is not available for director position of the bank that should be implemented in PBI Number 11/33/PBI/2009.

Table 1. Same Occupation in Several Islamic Banks in Indonesia

\begin{tabular}{|cccccc|}
\hline No. & $\begin{array}{c}\text { Name of } \\
\text { Bank }\end{array}$ & Position & $\begin{array}{c}\text { Related Position } \\
\text { (YES/NOT/?) }\end{array}$ & \multicolumn{2}{c|}{ Yisclosure } \\
\hline 1. & BMI & Director & YES & YES & \\
& & Commissioner & YES & YES & \\
& & DPS & YES & YES & \\
\hline 2. & Islamic Bank & Director & $?$ & & NOT \\
& A & Commissioner & ? & & NOT \\
& & DPS & YES & YES & \\
\hline
\end{tabular}




\begin{tabular}{|cccccc|}
\hline 3. & BSM & Director & NOT & YES & \\
& & Commissioner & $?$ & & NOT \\
& & DPS & YES & YES & \\
\hline 4. & BNI Syariah & Director & NOT & YES & \\
& & Commissioner & $?$ & & NOT \\
& & DPS & YES & YES & \\
\hline 5. & BRI Syariah & Director & NOT & YES & \\
& & Commissioner & YES & YES & \\
& & DPS & YES & YES & \\
\hline 6. & BJB Syariah & Director & $?$ & & NOT \\
& & Commissioner & YES & YES & \\
& & DPS & YES & YES & \\
\hline
\end{tabular}

Source: Implementation Report of GCG in 2013: BMI, Islamic Bank A, BSM, BNI Syariah, BRI Syariah, BJB Syariah. Notes: (?) There is the same occupation but did not disclose. The report of GCG just said "according to the rules."

Furthermore, this study also found that there are four banks violated the implementation of GCG, namely, Islamic Bank A, BSM, BNI Syariah, and BJB Syariah. However, the Financial Service Authority (FSA) does not give sanction or punishment to these banks, while the punishment has been regulated in PBI Article 81, Number $11 / 33 / \mathrm{PBI} / 2009$. In addition, there are two others Islamic banks that meet the requirements of PBI regulation Number 11/33/PBI/2009; those are BMI and BRI Syariah.

\section{b. Shareholder Intervention}

Practically, shareholders can intervene in the work of the board of director. Similarly, the board of director can control shareholders. The Compliance Director of Islamic Bank A confirmed this shareholders' intervention as positive, constructive, and in accordance with GCG principles and prudential banking. In contrast, the Compliance Director of BSM states that shareholders should not intervene the work of board of director.

In certain case, an intervention can be done by shareholders through the position of director or commissioner as they have a coordination line between them. Based on the SE-BI Number 12/13/DPbS regulation, it 
is only a president director should act independently without being able to receive any outside intervention. The SE-BI also regulates that only independent commissioner requires controls from hareholder, another commissioner, and/or director. Therefore, referring to the above case, the BSM should manage the intervention form shareholders.

c. Legal Standing of Islamic Supervisory Board

The legal position of Islamic Supervisory Board (DPS) in Islamic Bank A can be illustrated by the chart below.

Chart 1. Position of DPS at Islamic bank a

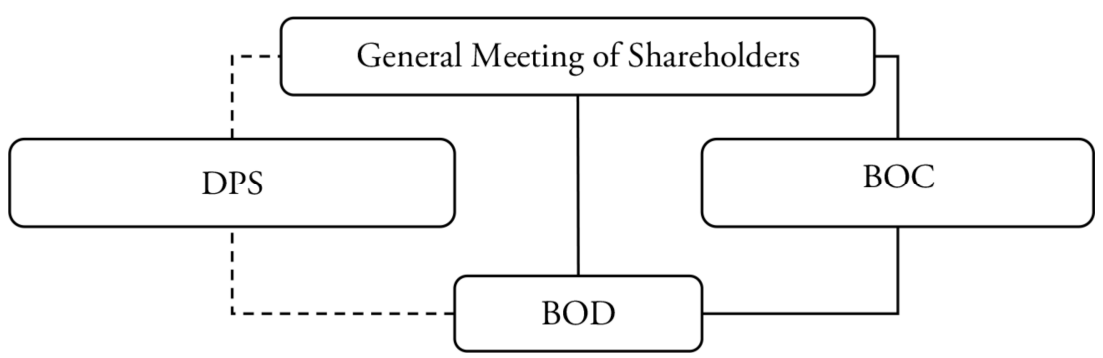

Source: Implementation Report of GCG in Islamic Bank A, 2013

The Chart above describes the structure of DPS and commissioner at Islamic Bank A as a supervisory body. The position of DPS is higher than the director. Mainly, the DPS has a role in giving an input to the director with or without the request. In addition, DPS also plays a supervisory role for product implementation or activity of the Islamic bank in accordance with Islamic principles. However, the DPS does not involve in decision making process of director on certain issue, except on the implementation of Islamic matter that is issued by Islamic Legal Opinion of Islamic National Board (Fatwa DSN). As a supervisory body, DPS has a task to conduct an Islamic audit, while the commissioner has a task to conducts an audit based on the banking management approach. 
Chart 2. Position of DPS at BSM

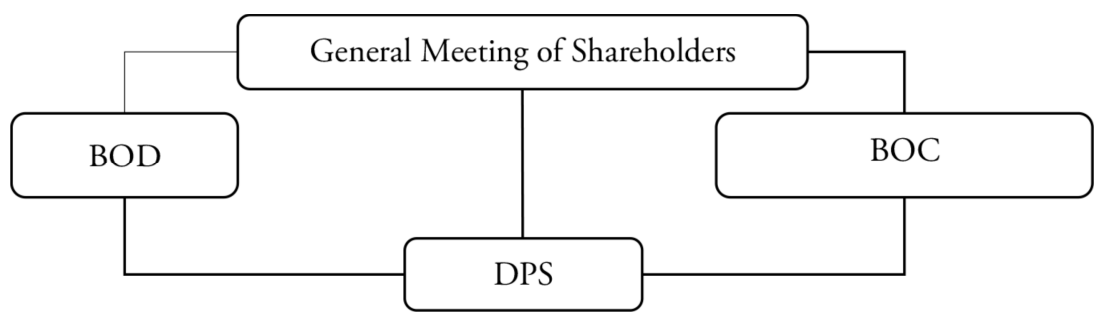

Source: Implementation Report of GCG Report in BSM, 2013

The role of DPS in BSM is to supervise the implementation of Islamic principles of banking activities. The board also examines and gives feedback to directors and commissioners of the bank based on the performance's results of the implementation of Islamic principles. As I mentioned earlier that the DPS also involves in decision making process related to manufacturing the new products when it is needed. By reviewing the contract agreement, DPS does pre-test through sampling to the work units to ensure operational implementation in accordance with Islamic principles.

Overall, based on the organizational structures available in Chart 1 and 2 shows that the position of DPS at Islamic Bank A and BSM represents two different interpretations. Firstly, the DPS has an equal position as the commissioner and director. Secondly, the position of DPS is lower that director and commissioner. The difference in interpretations is occurred due to the vagueness of the stakeholders in drafting the legislation. Moreover, the Limited Company (Ltd) Act also failed to understand the position of DPS in the regulation. There are at least three aspects that need to be considered as the main genuine element in the regulation, those are (1) The legal status of DPS; (2) the legal position of DPS that is equal to other Limited Company; and (3) the legal authority of DPS. As a result, business actors interpret the organizational structure differently.

In accordance with the law, the Limited Company should have responsibilities and authorities to manage the company. In fact, data from the field shows that the General Meeting of Shareholders (GMS), directors, and commissioners are considered as the main significant element of the Limited Company which have certain responsibilities 
and authorities to manage each position in the company. In other words, the DPS has a special position in Islamic banks to manage the halalness of Islamic bank products based on Islamic principles. Unfortunately, the position has not been accompanied by a legal status as "main organic element in limited company." Thus, the DPS does not have a legal position both in its status and authority.

\section{d. Duties of DPS, Board of Commissioners (BOC) and their Consequences}

Duties and responsibilities of DPS and BOC have regulated in the act of Islamic Bank and PBI. The Act of Islamic Bank No. 21 in 2008 states that regulations on requirements, number of duties, authorities, responsibilities, and other matters of the commissioners and directors of Islamic Banks are regulated in the Islamic banks .

Furthermore, the PBI Number 11/3/PBI/2009, article 24, section 1 states that the BOC supervises the implementation of duties and responsibilities of the BOD as well as provides advice to the BOD. The section 2 states that supervision by the BOC as referred to section 1 held in accordance with provisions of Central Bank of Indonesia (BI) concerning to implementation of Good Corporate Governance (GCG) which applicable for the bank (Darmadi, 2013). Detail of duties and responsibilities between DPS and the board of commissioner in Islamic bank is explained in Table 2 below.

Table 2. Duties and responsibilities between DPS and BOC

\begin{tabular}{|clll|}
\hline No. & \multicolumn{1}{|c|}{ Subject } & \multicolumn{1}{c|}{ DPS } & \multicolumn{1}{c|}{ BOC } \\
\hline $\begin{array}{l}\text { 1. } \\
\text { Number of } \\
\text { Person }\end{array}$ & $\begin{array}{l}\text { Minimum 1 (one) person from } \\
\text { an Islamic expert (Act of Limited } \\
\text { Company Article 109 sec. 2) }\end{array}$ & $\begin{array}{l}\text { Minimum 2 (two) people } \\
\text { of Commissioners Board } \\
\text { (Act of Limited Company } \\
\text { Article 1008 sec. 5) }\end{array}$ \\
\hline 2. & $\begin{array}{l}\text { Scope of } \\
\text { Duties and } \\
\text { Responsibilities }\end{array}$ & $\begin{array}{l}\text { Direct supervision on the process } \\
\text { of Islamic banking products from } \\
\text { the preparation of a product, the } \\
\text { operational stage and the post } \\
\text { operational stage }\end{array}$ & $\begin{array}{l}\text { Board of commissioner } \\
\text { supervise the implementation } \\
\text { of GCG in general, and not } \\
\text { concerning the products of }\end{array}$ \\
& $\begin{array}{l}\text { There are no committees that assist } \\
\text { the task of DPS, except staff (UU, } \\
\text { UUPS, PBI 11/33 PBI/2009, and } \\
\text { SE-BI 12/13/DPbS) }\end{array}$ & $\begin{array}{l}\text { Establish committees and } \\
\text { staff assisting tasks (Article } \\
121, \text { PBI 11/33/PBI/ 2009 } \\
\text { and SE-BI 12/13 / DPbS). }\end{array}$ \\
\hline
\end{tabular}




\begin{tabular}{|llll|}
\hline 3. $\begin{array}{l}\text { Nature of } \\
\text { Duties and } \\
\text { Responsibilities }\end{array}$ & $\begin{array}{l}\text { Duties and responsibilities are } \\
\text { heavier because they are bigger, } \\
\text { clearer, and more detail. If } \\
\text { negligent, the bank permit is } \\
\text { revoked and the prohibition to } \\
\text { become a DPS maximum 10 years. }\end{array}$ & $\begin{array}{l}\text { Duties and responsibilities } \\
\text { are applied only in general } \\
\text { to the implementation } \\
\text { of corporate governance } \\
\text { because it is unclear and } \\
\text { has no details and negligent } \\
\text { with no sanctions. }\end{array}$ \\
\hline 4. $\begin{array}{lll}\text { The target of } \\
\text { Duties and } \\
\text { Responsibilities }\end{array}$ & $\begin{array}{l}\text { More responsible for the } \\
\text { fulfillment of "Islamic principles" }\end{array}$ & $\begin{array}{l}\text { There are no obligation } \\
\text { and responsibility for the } \\
\text { products of Islamic banks. }\end{array}$ \\
\hline
\end{tabular}

Source: The Act of Limited Liability of Islamic Bank, PBI and SE-BI

To compare duties and responsibilities between DPS and BOC will be more interesting if we are also looking at the figures of remuneration and facilities which received by DPS and BOC (SE-BI Number 12/13/ $\mathrm{DPbS})$.

Table 3. Comparison of Remuneration and Facilities of Islamic Bank (in a Year)

\begin{tabular}{|c|c|c|c|c|c|c|c|}
\hline \multirow{3}{*}{ No. } & \multirow{3}{*}{$\begin{array}{l}\text { Name } \\
\text { of Bank }\end{array}$} & \multicolumn{6}{|c|}{ Remuneration and Other Facilities*) of Islamic Bank in a Year } \\
\hline & & \multicolumn{2}{|r|}{ BOD } & \multicolumn{2}{|r|}{ BOC } & \multicolumn{2}{|r|}{ DPS } \\
\hline & & Persons & IDR & Persons & IDR & Persons & IDR \\
\hline 1. & BSM & 6 & 35.956 .742 .381 & 3 & 10.813 .082 .142 & 3 & 1.201 .026 .000 \\
\hline 2. & BMI & 5 & 29.850 .000 .000 & 6 & 19.402.000.000 & 3 & 1.093 .000 .000 \\
\hline 3. & BRIS & 5 & 7.580 .000 .000 & 5 & 3.890 .000 .000 & 2 & 683.000 .000 \\
\hline 4. & $\begin{array}{l}\text { BJB } \\
\text { Syariah }\end{array}$ & 5 & 7.575 .000 .000 & 5 & 2.301 .000 .000 & 4 & 586.000 .000 \\
\hline 5. & $\begin{array}{l}\text { BNI } \\
\text { Syariah }\end{array}$ & 3 & 3.837 .666 .667 & 3 & 675.333 .333 & 2 & 442.500 .000 \\
\hline 6. & $\begin{array}{l}\text { Islamic } \\
\text { Bank A }\end{array}$ & 4 & 3.472 .500 .000 & 3 & 739.900 .000 & 2 & 199.600 .000 \\
\hline
\end{tabular}

*) are valued in equivalent IDR

Source: Implementation Report of GCG in 2013 BSM, BMI, BRI Syariah, BJB Syariah, BNI Syariah, and Islamic Bank A.

Table 3 shows an empirical fact that the renumeration and other facilities which received by BOD and BOC are higher than DPS within a year. The data shows that the remuneration and facilities which received by DPS is unbalanced with the directors and the board of commissioners get in each of Islamic bank in Indonesia. 
Table 4. Comparison the Remuneration of BOD, BOC, and DPS (in a Year)

\begin{tabular}{|c|c|c|c|c|c|c|c|c|c|c|c|c|c|c|c|c|c|c|}
\hline \multirow{2}{*}{$\begin{array}{l}\text { Amount of } \\
\text { Remuneration }{ }^{*} \text { ) Per- } \\
\text { person within } 1 \text { Year } \\
\text { (in IDR) }\end{array}$} & \multicolumn{3}{|c|}{ BSM } & \multicolumn{3}{|c|}{ BMI } & \multicolumn{3}{|c|}{$\begin{array}{l}\text { BRI } \\
\text { Syariah }\end{array}$} & \multicolumn{3}{|c|}{$\begin{array}{l}\text { BJB } \\
\text { Syariah }\end{array}$} & \multicolumn{3}{|c|}{$\begin{array}{c}\text { BNI } \\
\text { Syariah }\end{array}$} & \multicolumn{3}{|c|}{$\begin{array}{l}\text { Islamic } \\
\text { Bank A }\end{array}$} \\
\hline & $\begin{array}{l}\mathrm{B} \\
\mathrm{O} \\
\mathrm{D}\end{array}$ & $\begin{array}{l}\mathrm{B} \\
\mathrm{O} \\
\mathrm{C}\end{array}$ & $\begin{array}{l}\mathrm{D} \\
\mathrm{P} \\
\mathrm{S}\end{array}$ & $\begin{array}{l}\mathrm{B} \\
\mathrm{O} \\
\mathrm{D}\end{array}$ & $\begin{array}{l}\mathrm{B} \\
\mathrm{O} \\
\mathrm{C}\end{array}$ & $\begin{array}{l}\mathrm{D} \\
\mathrm{P} \\
\mathrm{S}\end{array}$ & $\begin{array}{l}\text { B } \\
\mathrm{O} \\
\mathrm{D}\end{array}$ & $\begin{array}{l}\mathrm{B} \\
\mathrm{O} \\
\mathrm{C}\end{array}$ & $\begin{array}{l}\mathrm{D} \\
\mathrm{P} \\
\mathrm{S}\end{array}$ & $\begin{array}{l}\text { B } \\
\text { O } \\
\text { D }\end{array}$ & $\begin{array}{l}\text { B } \\
\text { O } \\
\text { C }\end{array}$ & $\begin{array}{l}\mathrm{D} \\
\mathrm{P} \\
\mathrm{S}\end{array}$ & $\begin{array}{l}\mathrm{B} \\
\mathrm{O} \\
\mathrm{D}\end{array}$ & $\begin{array}{l}\mathrm{B} \\
\mathrm{O} \\
\mathrm{C}\end{array}$ & $\begin{array}{l}\mathrm{D} \\
\mathrm{P} \\
\mathrm{S}\end{array}$ & $\begin{array}{l}\text { B } \\
\text { O } \\
\text { D }\end{array}$ & $\begin{array}{l}\mathrm{B} \\
\mathrm{O} \\
\mathrm{C}\end{array}$ & $\begin{array}{l}\mathrm{D} \\
\mathrm{P} \\
\mathrm{S}\end{array}$ \\
\hline$>2$ Billion & 6 & & & 5 & 6 & & & & & & & & & & & & & \\
\hline$>1-2$ Billion & & & & & & & 5 & & & 1 & & & 3 & & & 1 & & \\
\hline $\begin{array}{l}>500 \text { Billion- } \\
\text { 1Billion }\end{array}$ & & 5 & & & & & & 5 & & 4 & & & & 1 & & 2 & & \\
\hline$<500$ Million & & & 3 & & & 3 & & & 2 & & 5 & 4 & & 2 & 2 & 1 & 3 & 2 \\
\hline
\end{tabular}

*) which received in financial form

Source: Implementation Report of GCG in 2013; BSM, BMI, BRI Syariah, BJB Syariah, BNI, and Islamic Bank A.

The Table above shows the data calculation based on the received renumateration by BOD, BOC, and DPS of each Islamic bank. DPS does not receive other facilities except remuneration. Similarly, the amount of remuneration in the form of money received by DPS is still under 500 million IDR in a year. Meanwhile, at the same time, the amount of remuneration received by directors and commissioners reached 500 million IDR up to one billion IDR. In fact, BOD and BOC of BSM have provided facilities and remuneration up to 2 billion IDR per year. The data above supports the results of interviews to some DPS in Islamic banks. It shows that DPS received small amount of money as it refers to SE-BI/12/13/DPbS that is under 100 million IDR per year.

The Financial Service Authority - Otoritas Jasa Keuangan (OJK) has been aware of this unbalancing and unjustice distribution of remuneration. The OJK states that the problem occured due to the ignorance of the Islamic bank to implement the principle of tawazun (balance) that is compatible to the right of remuneration for shareholders, directors, commissioners, DPS, and employees. The fact that the director has higher salary than the employees, the obligation to work harder is the employees. They also received unproper bonus and royalties from the bank. This problem has been reported to the bank, but it still continues. 


\section{The Islamic Expert in Islamic Bank}

a. Board of Director

PBI Number 11/33/PBI/2009 regulates a director's requirements in every Islamic bank. The requirements include to obey the provisions of $\mathrm{BI}$ and pay attention to the recommendations from the Remuneration and Nomination Committee. The SE-BI states that the director or the president director should come from independent parties. The successful of a president director is determined by his or her condition of not having a financial relationship, stewardship, share ownership, and/or family relationship with the BUS controlling shareholder (C1 of SE-BI Number 12/13/DPbS on April 30 ${ }^{\text {th }} 2010$ ).

Table 5. Composition of the BOD of the Islamic Bank in Indonesia

\begin{tabular}{|c|c|c|c|}
\hline $\begin{array}{l}\text { Names } \\
\text { of Bank }\end{array}$ & BOD & Position & $\begin{array}{c}\text { Education Background } \\
\text { (Graduated from) }\end{array}$ \\
\hline \multirow{6}{*}{ BSM } & Yuslam Fauzi & President Director & FE-UI, USA, and UI \\
\hline & Hanawijawa & Director & $\begin{array}{c}\text { AB-IPB University,Prasetya } \\
\text { Mulya }\end{array}$ \\
\hline & $\begin{array}{l}\text { Amran P. } \\
\text { Nasution }\end{array}$ & Director & $\begin{array}{c}\text { Faculty of Economic, } \\
\text { Trisakti }\end{array}$ \\
\hline & Sugiharto & Director & $\begin{array}{c}\text { UI Jember, UMJ, } \\
\text { Tarumanegara University } \\
\text { (UNTAR) }\end{array}$ \\
\hline & Zainal Fanani & Director & Faculty of Engineering ITS \\
\hline & $\begin{array}{l}\text { Ahmad } \\
\text { Syamsudin }\end{array}$ & Director & $\begin{array}{l}\text { IPB University, Int. } \\
\text { University of Japan }\end{array}$ \\
\hline \multirow{5}{*}{ BMI } & Arviyan Arifin & President Director & ITB \\
\hline & Andi Buchari & Director & IPB University, Atmajaya \\
\hline & $\begin{array}{l}\text { Adrian } \\
\text { Asharyanto }\end{array}$ & Director & $\begin{array}{c}\text { FE-UI, Erasmus Universiteit } \\
\text { Netherlands }\end{array}$ \\
\hline & Luluk Mahfudah & Director & Brawijaya University \\
\hline & Hendiarto & Director & FE-UI \\
\hline \multirow{4}{*}{$\begin{array}{l}\text { Bank } \\
\text { Victoria } \\
\text { Syariah } \\
\text { (BVS) }\end{array}$} & Ani Murdiati & President Director & Not Disclosed \\
\hline & Sari Idayanti & Director & Not Disclosed \\
\hline & Sutrisno Yulianto & Director & Not Disclosed \\
\hline & Djoko Nugroho & Director & Not Disclosed \\
\hline
\end{tabular}




\begin{tabular}{|c|c|c|c|}
\hline \multirow{4}{*}{$\begin{array}{c}\text { BNI } \\
\text { Syariah }\end{array}$} & Dinno Indiano & President Director & FE-Padjajaran University \\
\hline & $\begin{array}{l}\text { Imam Teguh } \\
\text { Saptono }\end{array}$ & Director & IPB \\
\hline & Acep Riana & Director & ITB, UI, IPB \\
\hline & Junaidi Hisom & Director & $\begin{array}{c}\text { FE-Sriwijaya University, } \\
\text { IPWI (Private University in } \\
\text { South Jakarta) }\end{array}$ \\
\hline \multirow{5}{*}{$\begin{array}{c}\text { BJB } \\
\text { Syariah }\end{array}$} & A. Riawan Amin & President Director & Not Disclosed \\
\hline & Ali Nurdin & Director & Not Disclosed \\
\hline & Didi Muwardi & Director & Not Disclosed \\
\hline & Humara Adam & Director & Not Disclosed \\
\hline & $\begin{array}{c}\text { Mochamad } \\
\text { Mujib Mas'ud }\end{array}$ & Director & Not Disclosed \\
\hline \multirow{5}{*}{$\begin{array}{c}\text { BRI } \\
\text { Syariah }\end{array}$} & $\begin{array}{l}\text { Moch. Hadi } \\
\text { Santoso }\end{array}$ & President Director & Not Disclosed \\
\hline & Ari Purwadono & Director & Not Disclosed \\
\hline & Eko S. Suharno & Director & Not Disclosed \\
\hline & Budi Wisakseno & Director & Not Disclosed \\
\hline & Indra Praseno & Director & Not Disclosed \\
\hline
\end{tabular}

Source : Implementation Report of GCG in 2013, BSM, BMI, BVS, BNI Syariah, BJB Syariah and BRI Syariah

The important aspect of developing an Islamic banking system is professional management administered by people who have expertise in the field of Islamic economic and Islamic economic law. The background gives guarantee to the society to believe the operational system of Islamic banks.

Table 5 above shows that most of members of the board of directors in several Islamic banks are coming from conventional banks. Based on their educational background, none of them has Islamic education both in Islamic economic and/or Islamic economic law. The previous study suggests that the position of DPS, as the highest approval authority for business system and products, requires skills and knowledge in both areas, conventional and Islamic approach (Hanif, 2018). 
The regulation maker has not been thinking about the implication of selecting a director of Islamic bank from a non-Islamic educational background. The requirements of having expertise in Islamic knowledge is needed to bridge the communication with the DPS and conventional banks in promoting Islamic banking system. The problem that might emerge of having someone from non-Islamic educational background is the possibility of having the model and culture of non-Islamic banking in the system. Say, for instance, the Bank Negara Malaysia (BNM) implements the Islamic Governance Framework (SGF) which obliged all Islamic banking to have a director with Islamic expertise.

\section{b. BOC and Key Person}

The Islamic expertise requirement is not applied to the board of commissioners. The regulation is available in PBI Number 11/33/ PBI/2009 and SE-BI Number 12/13/DPbS on April 30 th 2010. Therefore, reports from GCG (2013) of an Islamic bank in Indonesia found that none of commissioners has Islamic expertise. The reason why Islamic proficiency is required for an Islamic bank commissioner is because reading and evaluating financial statements especially on the application of Islamic accounting as well as reports of Islamic bank products which submitted by DPS required this knowledge.

\section{Several Cases of Fraud in Islamic Bank}

The Central Bank of Indonesia (BI) has formulated the term of fraud in PBI Number 12/28/DPNP. According to PBI Number 12/28/ DPNP, fraud is a deliberate act or omission which is intentionally committed to deceive and manipulate the bank, customer, or other parties, which taking place in the bank area and/or using the bank facilities causing the bank, customer or other parties to suffer loss and/ or fraud perpetrator obtains financial gain either directly or indirectly. The types of deeds which classified as fraud are cheating, deception, embezzlement of assets, information leakage, banking crime, and other actions that can be equated with it.

One of the causes of fraud is the communication gap between shareholders and the directors. Therefore, to prevent fraud, directors need to be professional or free from other party's interest. There is other 
type of fraud that is commonly found in the Islamic banking that is fraud by need or fraud that happened due to personal needs.

Table 6. Total Fraud in several Islamic Bank in Indonesia

\begin{tabular}{|l|cccccc|}
\hline \multirow{2}{*}{ Bank } & \multicolumn{4}{c|}{ Number of Cases which Performed by Employees } \\
\cline { 2 - 7 } & \multicolumn{2}{c|}{ BOD and BOC } & $\begin{array}{c}\text { Permanent } \\
\text { Employees }\end{array}$ & $\begin{array}{c}\text { Temporary } \\
\text { Employees }\end{array}$ \\
\cline { 2 - 7 } & $\mathbf{2 0 1 2}$ & $\mathbf{2 0 1 3}$ & $\mathbf{2 0 1 2}$ & $\mathbf{2 0 1 3}$ & $\mathbf{2 0 1 2}$ & $\mathbf{2 0 1 3}$ \\
\hline BSM & 0 & 0 & 19 & 34 & 16 & 8 \\
BMI & 0 & 0 & 0 & 0 & 1 & 1 \\
BVS & 0 & 0 & 1 & 1 & 0 & 0 \\
BRI Syariah & - & - & 15 & 21 & - & - \\
BNI & - & - & 2 & 3 & - & 1 \\
Syariah & & & & & & \\
\hline
\end{tabular}

Source: Implementation Reports of GCG based on Individual Islamic Banks, 2013

Authors also encountered some fraud cases in the media, such as:

a. Customer's fund's embezzlement occurred in BNI Syariah at Branch Office Lubuk Lingau with a total amount of loss is 8.1 billion IDR.

b. Danamon Bank sold its derivative products to Danamon Islamic Bank (UUS) customers.

c. Three BSM bank officials in Bogor bribed 9.3 billion IDR costumers' fund. Other cases of embezzlement occurred in the form of fictitious credit, with a total amount of loss is 102 billion IDR. This case involved a notary.

d. BSM's employees steal a 75 billion IDR customer's fund to buy a luxury house and car.

\section{Fraud Reports and Legal Issues}

The SE-BI establishes the obligation for Islamic banks to report the implementation of their corporate governance. The SE-BI also obliges the banks to reveal an internal fraud that may occur in the system, 
which includes: 1) numbers of internal frauds happened in the system; 2) numbers of ongoing internal frauds; 3) numbers of internal frauds that have not been pursued; and 4) numbers of internal frauds that followed up by legal process.

Based on table 6 above, most of the fraud actors are, first, the owner of the company or the largest shareholders; second, CEO, directors, commissioners, or head of branch; third, financial managers, accountants, public accountants in collaboration with the CEO/ Management; fourth, service providers such as notaries, or consultants which working together with employees of Islamic banks or customers; fifth, the company itself.

The table indicates that companies need to implement corporate governance for their banking system into Islamic corporate governance. By implementing Islamic corporate governance in the banking system will improve the performance of banking activities and the customer's trust. Hopefully, cases such as illegal actions and fraud will happen less.

The effort of BI to tackle fraud, money laundering and other risk management needs to be decentralized. BI has include antifraud policy in the SE-BI regulation, Number 13/28/DPNP on December $9^{\text {th }}$, 2011 on the 'Implementation of Anti-Fraud Strategy for Commercial Banks'; PBI Number 13/23/PBI/2011 on the 'Implementation of Risk Management for BUS and UUS', and PBI Number 14/27/PBI / 2012 on the 'Implementation of Anti-Money Laundering Program and the Prevention of Terrorism Financing for Commercial Banks'.

According to Rezaee (2011), the Islamic corporate governance is important to be implemented by the regulation maker to create internal anti-fraud regulations for elite officials of the bank such as directors, management, internal auditors, and external auditors. Moreover, it is also important to add fraud rules to shareholders, commissioners, DPS, and other affiliated parties. In addition, OJK and BI should emphasize this rule to directors, board of commissioners, DPS, Branch Chief, and other key people in Islamic banks by obliging them to report their and family members' wealthy to the Center for Reporting and Analysis of Financial Transaction (PPATK). 


\section{Conclusion, Limitations and Futher Research}

This research concludes that the corporate governance regulation in Islamic banks in Indonesia does not philosophically base on AlQur'an and Hadith. The principles of GCG which issued by BI does not refer to general Islamic values or like a reflection of the morals of the Prophet Muhammad SAW, namely, Shiddiq (right), Fathanah (intelligent), Amanah (trustee), Tabligh (deliver), Adil (fairness), Ihsan (goodness), Tawazun (balance), and so forth. Furthermore, referring to the positive law, this research found that unclear regulation could create more fraud in Sharia Bank. Some weaknesses which are occurred in Islamic bank are the low position of DPS in organization structure, low skills and knowledge on sharia particularly for directors and commissioners, numbers of personel of DPS and commissioners do not meet the regulation's standard.

Regarding the punishment, the DPS member received more severe punishment than the commissioners. The DPS member received a lower quantity of renumeration and received fewer facilities compared to the director and commissioner. In this regard, the corporate governance regulations in Islamic banks need to be revised and change it into Islamic corporate governance based on Islamic principles and national laws. Finally, this study supports Chodhury and Alam's (2013) study which found that the goal of the implementation of CG is not to achieve a financial goal but a substantive value which is an important aspect in the process of management coordination and cooperation. The practice of CG in Islamic bank is far from perfect.

\section{Acknowledgment}

This article is a result of an in depth- research on Corporate Governance in Islamic Banks that is financially supported by State Islamic University of Syarif Hidayatullah Jakarta, Indonesia. We are really thankful to State Islamic University of Syarif Hidayatullah Jakarta.

\section{References}

Act of Islamic Bank No. 21 The Year of 2008, Article 34.

Abeng, T. (1997). "Business Ethics in Islamic Context: Perspectives of a Muslim Business Leader." Phyloshopy Documentation Center: Business Eyhics Quartely, Vol. 7, No. 3: 47. https://www.pdcnet.org accessed on December 7th, 2012). 
Islamic Bank A, (2015). Interview with Compliance Director of Bank A Shariah. Jakarta: Bank A Shariah on February $4^{\text {th }}$.

Bank Syariah Mandiri, (2015). Interview with Compliance Director of BSM on February $5^{\text {th }}$. Jakarta.

Cadbury, A. (1992). "The Financial Aspect of Corporate Governance," London: Gee (a Division of Professional Publishing Ltd), First published December (1992): 14, www.ecgi.org and www.icaew.com, accessed on May 12 $2^{\text {th }}, 2014$.

Central Bank of Indonesia, PBI 11/33/PBI/2009 Article 1 No. 10 juncto Article 34.

Central Bank of Indonesia, PBI 11/33/PBI/2009 Article 16 and Article 50, www. bankindonesia, accessed on May $25^{\text {th }}, 2014$.

Central Bank of Indonesia, PBI 11/33/PBI/2009 Article 81, www.bankindonesia, accessed on May $27^{\text {th }}, 2014$.

Central Bank of Indonesia, PBI Number 11/33/PBI/2009 Article 18.

Central Bank of Indonesia, PBI Number 11/33/PBI/2009 Article 19.

Central Bank of Indonesia, SE-BI No.21/13/DPbs on April 30th, 2010 letter of G.p Central Bank of Indonesia, SE-BI No.12/13/DPbS on April 30th, 2010 letter of C 1. Central Bank of Indonesia, SE-BI No.13/28/DPNP on December 9th, 2011 regarding Implementation of Anti Fraud Strategy for Commercial Banks (Jakarta: Bank Indonesia, 2011), and I. General point 2 and Attachment I.

Central Bank of Indonesia, SE-BI No. 12/13/DPbS on April 30th, 2010 A. General, Number 2, www.bankindonesia.go.id, accessed on May 27 $7^{\text {th }}$ 2014.

Chodhury, M. A. and M.N. Alam. (2013)."Corporate governance in Islamic persepctive." International Journal of Islamic and Middle Eastern Finance and Management, 6 (3), 180-199.

Darmadi, S. (2013). "Corporate governance disclosure in the annual report: An explanatory study on Indonesian Islamic banks." Humanomics, 29 (1), 4-23.

Di Lorenzo, V. (2007). Business Ethics: Law as a Determinant of Business Conduct. Springer: Journal of Business Ethics, 71 (3), 275, www.jstor.org/ stable/25075333, accessed on November 26 $6^{\text {th }}, 2012$.

Franzini , S. (2009). "Corporate Governance in Theory and Practice." Spring; Journal of Politics and International Affair, www.myedu and www.bitlib.net, accessed on December 6th, 2012.

Hanif, M. (2018). "Shari'ah-compliance ratings of the Islamic financial services industry: a quantitative approach." ISRA International of Islamic Finance, 10 (2), 162-184.

Hasan, Z. (2009), "Corporate Governance: Western and Islamic Perspectives," International Review of Business Research Papers, 5(1) in January, www. bizresearchpaper.com (Accessed on May 26th, 2014).

Interview informally with some DPS of Islamic bank. Identity is kept secret for the common good. 
Klapper , Leora F., Inessa L. (2004).“Corporate Governance, Investor Protection, and Performance in Emerging Markets." Journal of Corporate Finance, 10(5), 703, www.sciencedirect.com/science/journal/09291199/ and www.elibrary. worldbank.org, accessed on November $8^{\text {th }}, 2012$.

Lasghari, M. (2004). "Corporate Governance: Theory and Practice," The Journal of American Academy of Business, Cambridge. 5,(1 and 2). www.indabook. org, accessed on December $6^{\text {th }}, 2012$.

Lewis, Mervyn, K. (2007). "Islamic Banking in Theory and Practice." Monash Business Review, 3 (1), www.iefpedia.com/, accessed on June 17 $7^{\text {th }}, 2013$.

Liun, Sean (2005). "Corporate Governance and Development: The Case of China." Willey-Blackwell: Managerial and Decision Economics, 26 (7),Corporate Governance: An International Perspective (Oct-Nov, 2005): 445, onlinelibrary. wiley.com, accessed on November 17th, 2012.

Marlina, R. (2015). Interview with BSM Compliance Division. Jakarta: BSM on February $5^{\text {th }}$.

Masulis, Ronald W., Cong Wang, and Fei Xie. (2007). “Corporate Governance and Acquirer Returns." Wiley-Blackwell: The Journal of Finance, 62(4), 1851. Available at www.onlinelibrary.wiley.com, ccessed on December 6 ${ }^{\text {th }}, 2012$.

KNKCG, Jakarta: Coordinating Minister for Economic Affairs, 1999.

National Committee on Governance Policy (2006). "Guidelines of Good Corporate Governance of Indonesia Year of 2006.” Jakarta: KNKG, 2006, 1

Rezaee, Z. Z. (2011). “Anti Fraud Role of Corporate Gatekeepers.” Kuala Lumpur Malaysia: International Conference on Financial Criminology, UiTM, June 9th, 2011

The Republic of Indonesia, Decree of the Coordinating Minister of Economy Number: EP/31/M.EKUIN/08/1999 on National Committee on Corporate Governance Policy.

R. Eko Irianto, Interview with Department of Islamic Bank OJK . Jakarta: on February $25^{\text {th }}, 2015$.

Central Bank of Indonesia, SE-BI No. 12/13/DPbS on April 30th, 2010 to all Full-Pledge (BUS) and Sharia Unit Business (UUS) in Indonesia about of Implementation of Good Corporate Governance for BUS and UUS. Jakarta: Central Bank of Indonesia, 2010, 27-28 and 34.

Somad, A. (2012). Hukum Islam: Penormaan Prinsip Shariah dalam Hukum Indonesia (Islamic Law: Norms of Islamic Principles in the Perspective of Indonesian Law) Jakarta: Kencana Prenada Media Group, Revision Edition, pp. 84-091.

Suma, Muhamad A. (2002). "Ekonomi Syariah sebagai Alternatif Sistem Ekonomi Konvensional (Islamic Economic as the alternative of Conventional Economic System)." Jurnal Hukum Bisnis (Journal of Lawand Business), XX(18)

Sundaram, Anant K. and Andrew C. Inkpen (2004). "Stakeholder Theory and The Corporate Objective Revisited: A Reply." INFORMS: Organization Science, 15(3), 370, www.thunderbird.edu, accessed September 26th, 2012. 
Trunbull. (1999). "Internal Control Guidance for Directors on the Combined Code." London: The Institute of Chartered Accountants in England and Wales, p. 4-6, www.jstor.org/stable/3867928 and www.ecgi.org. (Accessed at Mei, 12nd 2014); See too at Arif Effendi, The Power of Good Corporate Governance Theory and Implementation (Jakarta: Salemba Empat, 2009), 1.

http//palembang-pos.com/Sunday, October 14 ${ }^{\text {th }}, 2012$, accessed on Wednesday, February $12^{\text {th }}, 2014$

http://komnaslkpipusat.blogspot.com//2013/06/06, accessed on Wednesday, February $12^{\text {th }}, 2014$

http://m.bisnis.com/Monday, Monday, 04 November 2013, 18:29 WIB, accessed on Wednesday, February $12^{\text {th }}, 2014$

http://megapolitan.kompas.com/, Monday, 24 October 2013, 23:49 WIB, accessed on Wednesday, February $12^{\text {th }}, 2014$

http://jawapos.com/Monday, 3/02/15, 05:03, 18:29WIB, accessed on February $2^{\text {nd }}, 2015$. 